\title{
Transcriptional Regulation of stj Fimbrial Operon in Salmonella Typhimurium
}

\author{
Deniz YÜKSEL ${ }^{1}$, Nefise AKÇELİK ${ }^{2}$, Mustafa AKÇELİK ${ }^{1}$ \\ ${ }^{1}$ Ankara University, Faculty of Science, Biology Department; ${ }^{2}$ Ankara University, Biotechnology Institute, Ankara.
}

\begin{abstract}
Summary: The stj fimbrial operon harbors five genes, $s t j A B C D E$. The operon plays role in the persistence and virulence of $S$. Typhimurium in host systems. In this study, in vitro activation of the stj operon was achieved by transposon (TPOP) mutagenesis. The transposon insertion site was located within the $c a d C$ gene promoter in the stj operon-activated mutant strain MDN20. Comparative analysis of two-dimensional gel electrophoresis protein patterns of the wild type strain (S. Typhimurium LT2) and mutant strain MDN20 revealed that the CadC and StjB proteins were produced by mutant strain MDN20 but not by the wild type strain. These results were also confirmed by Maldi-TOF analysis. These findings indicate that cadC gene is a transcriptional activator of $s t j$ fimbrial operon in $S$. Typhimurium.
\end{abstract}

Key words: $S$. Typhimurium, stj operon, $c a d C$, transcriptional activator.

\section{Salmonella Typhimurium'da stj fimbriyal operonunun transkripsiyonel regülasyonu.}

Özet: Salmonella Typhimurium'da konakçı sistemde kalıcılığı ve virulensliğinde rol oynayan stj fimbriyal operonu, stjABCDE olmak üzere beş gen içermektedir. Bu çalışmada, stj fimbriyal operonunun in vitro koşullarda aktivasyonu transpozon (TPOP) mutasyonu yolu ile gerçekleştirildi. stj operonu aktive edilen mutant suşta (MDN20), traspozonun cadC geni promotoruna girdiği belirlendi. Doğal suş ( $S$. Typhimurium LT2) ve MDN20 mutant suşunda gerçekleştirilen iki yönlü jel elektroforezi çalışmaları sonucunda; $\mathrm{CadC}$ ve StjB proteinlerinin doğal suşta üretilmediği, ancak MDN20 mutant suşunda üretildiği saptandı. Bu sonuçlar ayrıca Maldi-TOF analizleri ile de doğrulandı. Bu bulgular, $S$. Typhimurium'da cadC geninin, stj operonunun transkripsiyonel aktivatörü olduğunu gösterdi.

Anahtar sözcükler: $S$. Typhimurium, stj operonu, $c a d C$, transkripsiyonel aktivatör.

\section{Introduction}

S. Typhimurium genome contains 13 fimbrial operons named agf(csg), fim, lpf, pef, bcf, stb, ste, std, stf, sth, sti, saf and stj. As a result of comparative sequence analyses, stj fimbrial operon is only detected in $S$. Typhimurium genome. This finding suggested that $\mathrm{Stj}$ fimbria could have a role as serovar-specific virulence factor in $S$. Typhimurium $(3,21,23)$. However, no studies existed in current literature indicating the role of this fimbria in virulence and persistence in host systems of $S$. Typhimurium until 2009. Akkoç et al. (1) identified the role of the stj fimbriyal operon in the long-term persistence of $S$. Typhimurium by competitive infection experiment using a group of four genetically resistant mouse (CBA) model systems. In that study, stj mutant MA44 $\left(\mathrm{phoN}^{+}\right)$and a phoN mutant strain AJB715 $\left(s t j^{+}\right)$ were mixed at equal volumes and four resistant CBA mice were orally inoculated with this mixture. Mice fecal samples were collected at days 3, 7, 9, 14, 17, 21, 25, 28, 30 and 34 after inoculation. Luria Bertani (LB) agar plates containing appropriate antibiotics (kanamycin [100 $\mu \mathrm{g} / \mathrm{mL}]$ and nalidixic acid $[50 \mu \mathrm{g} / \mathrm{mL}])$ and 5-bromo-4chloro-3-indolyl-phosphate (BCIP) were used for enumerating stj mutant MA44 $\left(\mathrm{phoN}^{+}\right.$, blue) and competing strain AJB715 (phoN', white) colonies by plate count method. After 34 day period of the experiment, stj mutant MA44 was recovered at significantly lower numbers $(p<0.05)$ than the competing strain AJB715. Furthermore, from peripheral site samples (spleen, cecum and mesenteric lymph nodes), the $s t j$ mutant MA44 was less able to colonize the tissues than the wild type strain AJB715 ( $<<0.05)$. These results indicate that $s t j$ fimbrial operon has an important role in the colonization and long-term intestinal persistence of $S$. Typhimurium in mice.

Identification of the crucial role of the stj fimbrial operon in $S$. Typhimurium pathogenicity would aid in understanding its genetic regulation. The aim of the present study was to identify the characteristics of the genetic regulation of $s t j$ fimbrial operon by genomic and proteomic analyses of $S$. Typhimurium mutants. 


\section{Materials and Methods}

Transposon mutation: For transposon mutation, 1\% of overnight $S$. Typhimurium MA2 (StjE::LacZYA, $\mathrm{Carb}^{\mathrm{R}}, \mathrm{Cm}^{\mathrm{R}}$ ) strain was inoculated into LB broth media supplemented with appropriate antibiotics and incubated at $37^{\circ} \mathrm{C}$ for 12 hours with $200 \mathrm{rpm}$ agitation. Following the incubation, $0.1 \mathrm{~mL}$ of donor strain was mixed with $0.1 \mathrm{~mL}$ of $\mathrm{p} 22$ phage transduction broth containing $\mathrm{T}$ POP transposon and the mixture was incubated at $37^{\circ} \mathrm{C}$ for $30 \mathrm{~min}$. The mutants were screened on LB agar plates containing tetracycline (Tet) and 5-bromo-4-chloro-3indolyl- $\beta$-D-galactopyranoside (X-gal). After incubation at $37^{\circ} \mathrm{C}$ for 18 hours, dark blue colonies were selected and inoculated onto both LB agar containing Tet and XGal, and to LB containing only X-Gal, and incubated at $37^{\circ} \mathrm{C}$ for 18 hours. Following incubation, colonies, which were white on $\mathrm{LB}+\mathrm{X}-\mathrm{Gal}$, but dark blue on $\mathrm{LB}+\mathrm{Tet}+\mathrm{X}-\mathrm{Gal}$, or colonies which were dark blue on both of the LB plates were inoculated into LB broth supplemented with tetracycline $(15,17)$. The $\beta$ galactosidase activity of these colonies were measured as described by Miller(13).

Inverse PCR: For mutants with high $\beta$-galactosidase activity, the insertion site of transposon was identified by sequence analysis of the fragment amplified with inverse PCR using specific primers (Forward 5'CGCTTTTCCCGAGATCATATG-3' and Reverse 5'GCACTTGTCTCCTGTTTACTCC-3'). For the inverse PCR, DNA flanking the T-POP insertions was amplified using GeneAmp9700 Thermocycler (Applied Biosystems, USA). The final concentration of reagents in the PCR reaction mix (20) were as follows: $36 \mu \mathrm{L}$ PCR grade water, 10X PCR buffer $\left(\mathrm{MgCl}_{2}\right.$, Fermantas, Finland), $2 \mathrm{mM}$ dNTP mix, 20 pmol of each primer, $2 \mathrm{mM} \mathrm{MgCl}_{2}$ (25mM $\mathrm{MgCl}_{2}$, Fermentas, Finlandh), $1.25 \mathrm{U}$ Taq DNA polymerase (5 U/mL, Fermantas, Finland) and $2 \mu \mathrm{L}$ template DNA (approximately $200 \mathrm{ng}$ ). The PCR conditions were as follows: initial activation of the TaqDNA-Polymerase for $5 \mathrm{~min}$ at $94^{\circ} \mathrm{C}$, followed by 30 cycles of $30 \mathrm{sec}$ denaturation at $94^{\circ} \mathrm{C}$, annealing for 1 $\min$ at $55^{\circ} \mathrm{C}$, and extension for $5 \mathrm{~min}$ at $72^{\circ} \mathrm{C}$. The program ended with a $10 \mathrm{~min}$ fill-in step at $72^{\circ} \mathrm{C}$.

Total protein extraction: Total protein extractions of $S$. Typhimurium strains were performed according to the method described by Bradford (2). Salmonella strains were grown in $20 \mathrm{~mL} \mathrm{LB}$ broth medium at $37^{\circ} \mathrm{C}$ for $12 \mathrm{~h}$ (with $200 \mathrm{rpm}$ agitation). Growing cells were harvested by centrifugation (1200 rpm, $2 \mathrm{~min}$ ) and resuspended in lysis buffer $(\mathrm{NaCl}, 0.43 \mathrm{~g}$; EDTA, $0.09 \mathrm{~g}$; Tris- $\mathrm{HCl}$, $0.3 \mathrm{~g}$; protease inhibitor, distilled water, $50 \mathrm{~mL}$; $\mathrm{pH} 7.5 \pm$ 0.02). Resuspended cells were incubated in an ultrasonic water bath (35kHz, Transsonic 570/H, Elma, USA) for 3 min, and sonicated with an ultrasonic processor (Sonics,
Vibra cell, Taiwan). After sonication, the cell debris was removed by centrifugation (14000 rpm, $10 \mathrm{~min}$ ). Protein concentrations of each solubilized sample were assessed using bovine serum albumin as a standard protein to ensure equal loading of each preparation (2).

2D gel analysis: 2D gel analysis of total $S$. Typhimurium proteins were carried out using the BioRad 2D Electrophoresis system (Bio-Rad, USA). Samples containing $175 \mu \mathrm{g} / \mathrm{mL}$ of protein was mixed with rehydration solution containing $8 \mathrm{M}$ urea, 2\% CHAPS (3-[(3-cholamidopropyl)-dimethylammonio]-1propanesulfonate), $0.5 \%$ IPG Buffer, $0.02 \%$ bromphenol blue, with DTT $(2.8 \mathrm{mg} / \mathrm{mL})$ and, were loaded into 17 cm IPG strips ( $\mathrm{pH}$ 5-8, Bio-Rad, USA). Strips were rehydrated for $15 \mathrm{~h}$ at $30 \mathrm{~V}$. Isoelectric focusing (IEF) with IPG gel strips was initiated at $250 \mathrm{~V}$ for $15 \mathrm{~min}$ and gradually ramped to $10.000 \mathrm{~V}$ over $5 \mathrm{~h}$, and remained at $10.000 \mathrm{~V}$ for an additional $6 \mathrm{~h}$. The focused IPG strips were equilibrated twice for $15 \mathrm{~min}$ in each of the following equilibration buffers, A and B [(Solution A) 50 $\mathrm{mM}$ Tris/HCl, pH 6.8, 6M Urea, 30\% (v/v) glycerol, 4\% (w/v) SDS, with $3.5 \mathrm{mg}$ DDTT $\mathrm{mL}^{-1}$; (Solution B) $45 \mathrm{mg}$ iodoacetamide $\mathrm{mL}^{-1}$ instead of DTT]. In the second dimension, proteins were separated on $10 \%$ SDSpolyacrilamide gels run at $70 \mathrm{~V}$ for $45 \mathrm{~min}$, followed by $120 \mathrm{~V}$ for $8-10 \mathrm{~h} \mathrm{(6).} \mathrm{SDS-gels} \mathrm{were} \mathrm{stained} \mathrm{with}$ SYBRO Ruby Protein Gel Stain (Bio-Rad, USA) according to the manufacturer's instructions.

MALDI-TOF-MS analysis: Protein spots of interest were excised from the gels using PD Quest programme (Proteome Works Spot Cutter, Bio-Rad, USA) and analysed using Matrix-Assisted Laser Desorption/ Ionized-Time of Flight Mass Spectrometry (MALDITOF-MS). MALDI-TOF-MS analysis was carried out at Ankara University, Biotechnology Institute (Ankara, Turkey) by in-gel trypsin digestion and spectrometric analysis. Peptide mass fingerprints were identified by searching the Salmonella database NCBInr 20070512 (4914404 sequence entries) of the National Center for Biotechnology Information (NCBI) protein data base using Mascot MS/MS search engine (Matrix Science Ltd, London, UK) (18).

\section{Results}

S. Typhimurium MA2 mutant, with stjE::LacZYA fusion, generated by Akkoç et al. (1) was used in activation of $s t j$ fimbrial operon via transposon (T-POP) mutagenesis. Expression of $s t j$ fimbrial operon by phenotypic characterisation after transduction of T-POP transposon to $S$. Typhimurium MA2 mutant shows that it harboured the transposase gene. Following the p22 phage transduction, dark blue colonies were selected, and at this time inoculated onto both LB and LB containing Tet. $\beta$ - 
galactosidase activities of the colonies was measured as described previously (13). In the mutant, MDN20 strain, $\beta$-galactosidase activity levels were measured as 44 Miller Units (MU) and $380 \mathrm{MU}$ for LB agar and LB agar+Tet, respectively.

In this study, tetracycline was added to the growth media of mutant strains since T-POP transposon includes a tetracycline-inducible promoter. The $s t j$ fimbrial operon in $S$. Typhimurium MA2 was activated by induction of tetracycline promoter since T-POP transposon was inserted in the promotor of the gene that regulates the $s t j$ fimbrial operon. Mutants were grown in LB supplemented with Tet, and the T-POP promoter and also regulator gene were activated in order to achieve expression of the regulator. If the regulator were a negative regulator, depending upon tetracycline induction, inactivation of the $s t j$ fimbrial operon would be expected $(7,23)$. Significant increases in $\beta$ galactosidase activities of the MDN20 mutant pointed out that $s t j$ fimbrial operon regulated by a positive transcriptional regulator.

This observation was supported by sequence analysis of transposon insertion sites amplified by inverse PCR in stj fimbrial operon-activated mutants. AluI-digested genomic DNA samples from mutants were used as a template in the inverse PCR (Figure 1).

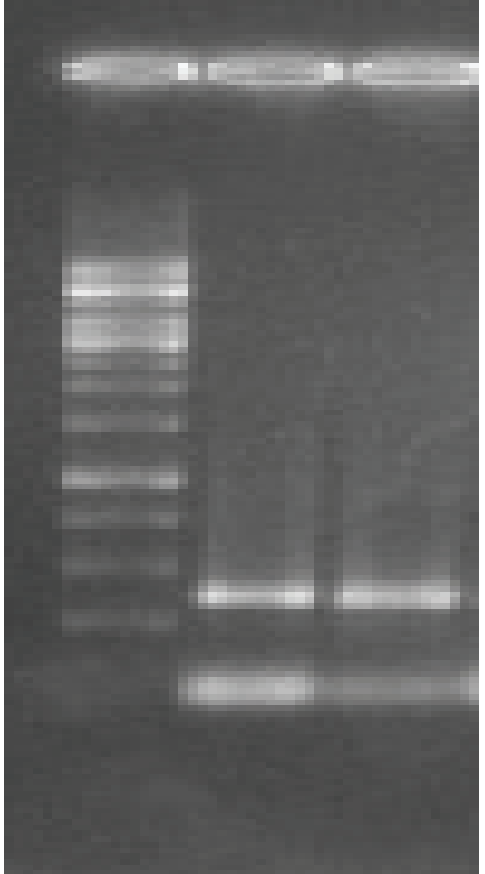

Figure 1: Inverse PCR products, obtained from chromosomal DNA sample of $s t j$ fimbrial operon activated mutant (MDN20) . Wells; 1: Marker DNA (250-10000 bp), 2-3: MDN20 DNA inverse PCR products.

Şekil 1: stj fimbriyal operonu aktive edilen mutant (MDN20) kromozomal DNA örneği üzerinde çoğaltılan ters yön PZR ürünleri. Kuyular; 1: Marker DNA (250-10000 bç), 2-3: MDN20 DNA ters PZR ürünleri.

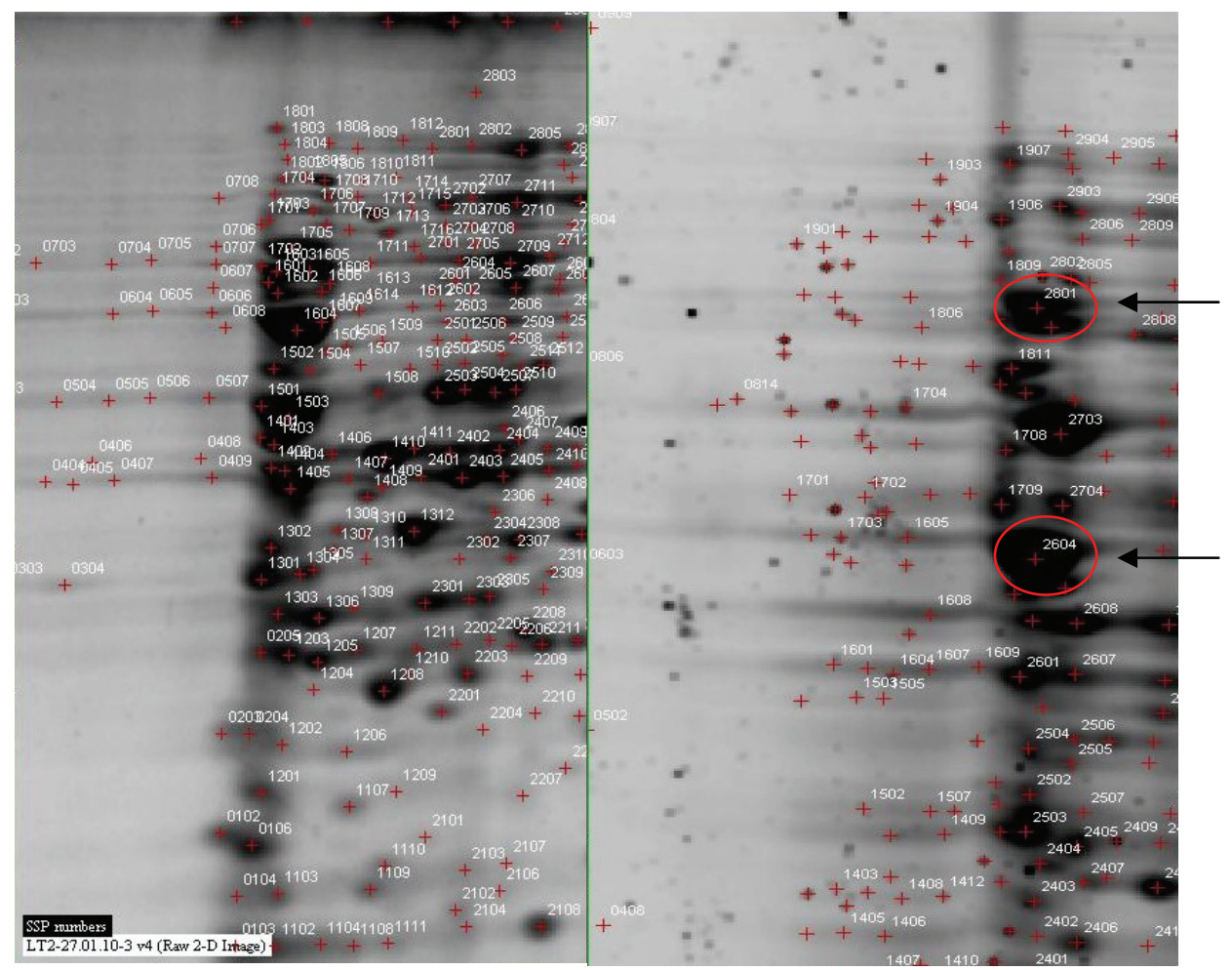

stjB

$\operatorname{cadC}$

Figure 2: Total protein profiles of MDN20 mutant strain, propagated with (A) and without (B) adding tetracycline in the growth medium.

Şekil 2: Tetrasiklin içermeyen (A) ve tetrasiklin içeren (B) ortamda geliştirilen MDN20 mutant suşuna ait toplam protein profilleri. 
Blast analysis of PCR-products sequence showed that T-POP transposon was inserted into the cadC gene of $S$. Typhimurium genome. This finding strongly supports the prediction of cadC gene as a positive regulator of the $s t j$ fimbrial operon. Also, a second result also supports this prediction as follows: protein synthesis patterns (i.e, the proteome) of MDN20 mutant strains grown in LB broth+Tet produced a high expression of $\mathrm{StjB}$ and CadC proteins in the MDN20 mutant grown in LB+Tet broth, but these proteins were not expressed in MDN20 mutant grown only in LB broth (Figure 2).

Results obtained from 2D gel electrophoresis were confirmed by trypsinization of $\mathrm{StjB}$ spots, excised from these gels, and followed by MALDI-TOF analysis. We then compared our results with the protein synthesis patterns of the wild type $S$. Typhimurium LT2 as a control. However expression of $\mathrm{stjB}$ ve CadC proteins were not investigated in $S$. Typhimurium LT2. As a result of the trypsin digestion in the MDN20 mutants, 1337.8943, 1602.1145, 1382.8025, 1239.1532, 1193.7943, 1189.9496, 1199.3779, 1375.3203 Dalton size eight common peptides showed expression of $\mathrm{stjB}$ protein (Figure 3); 1277.698, 1565.9673, 1030.4460 and 1379.4177 Dalton size four common peptide (Figure 4) showed expression of $\mathrm{CadC}$ protein. These findings certainly proved that the insertion site of the T-POP transposon in MDN20 mutant (CadC) activated the stj fimbrial operon.
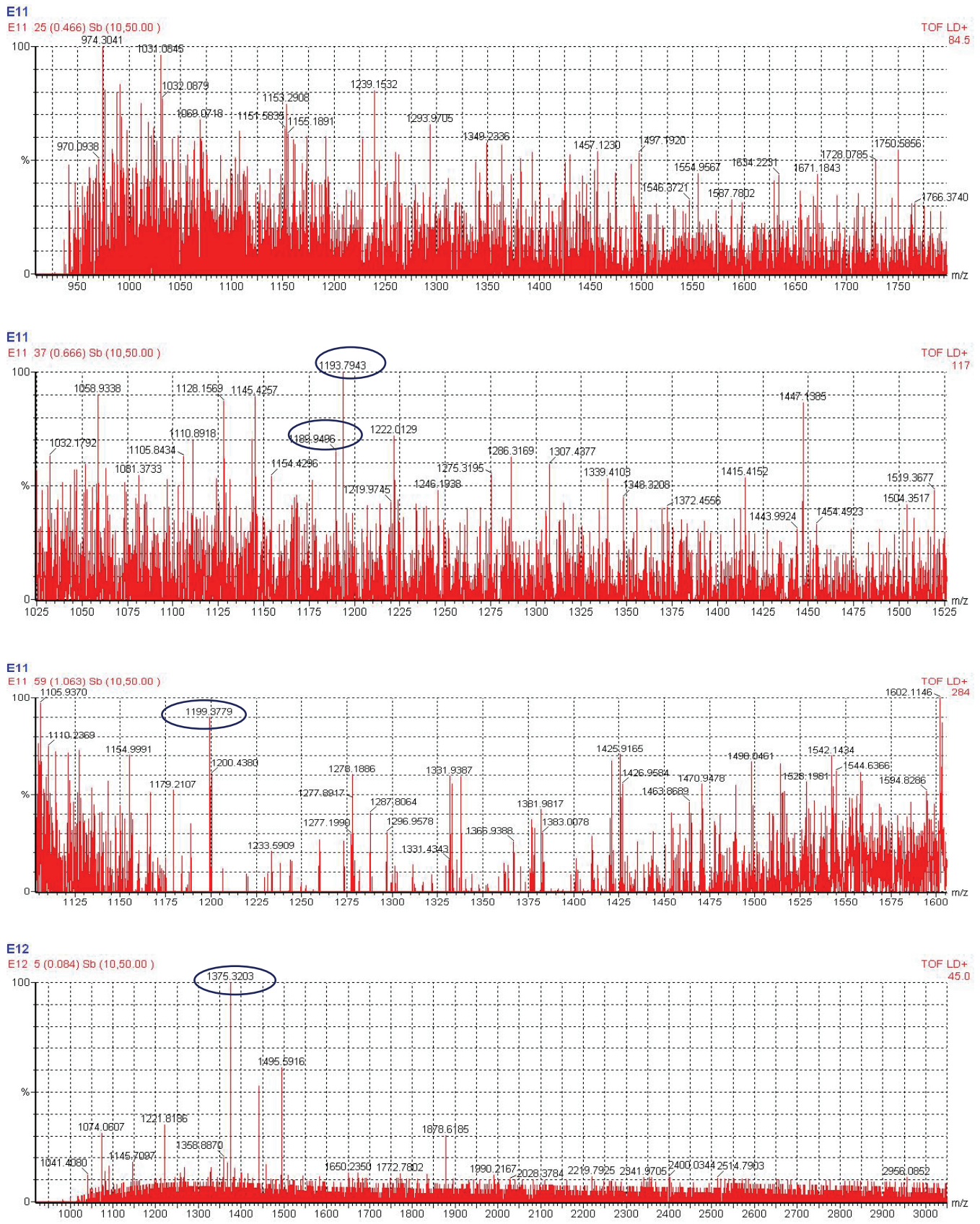

Figure 3: Peptides, identified by trypsinization of Stj protein spot of MDN20 mutant strain Şekil 3: MDN20 mutant suşuna ait Stj protein spotunda, tripsin kesimi sonucu tanımlanan peptitler 

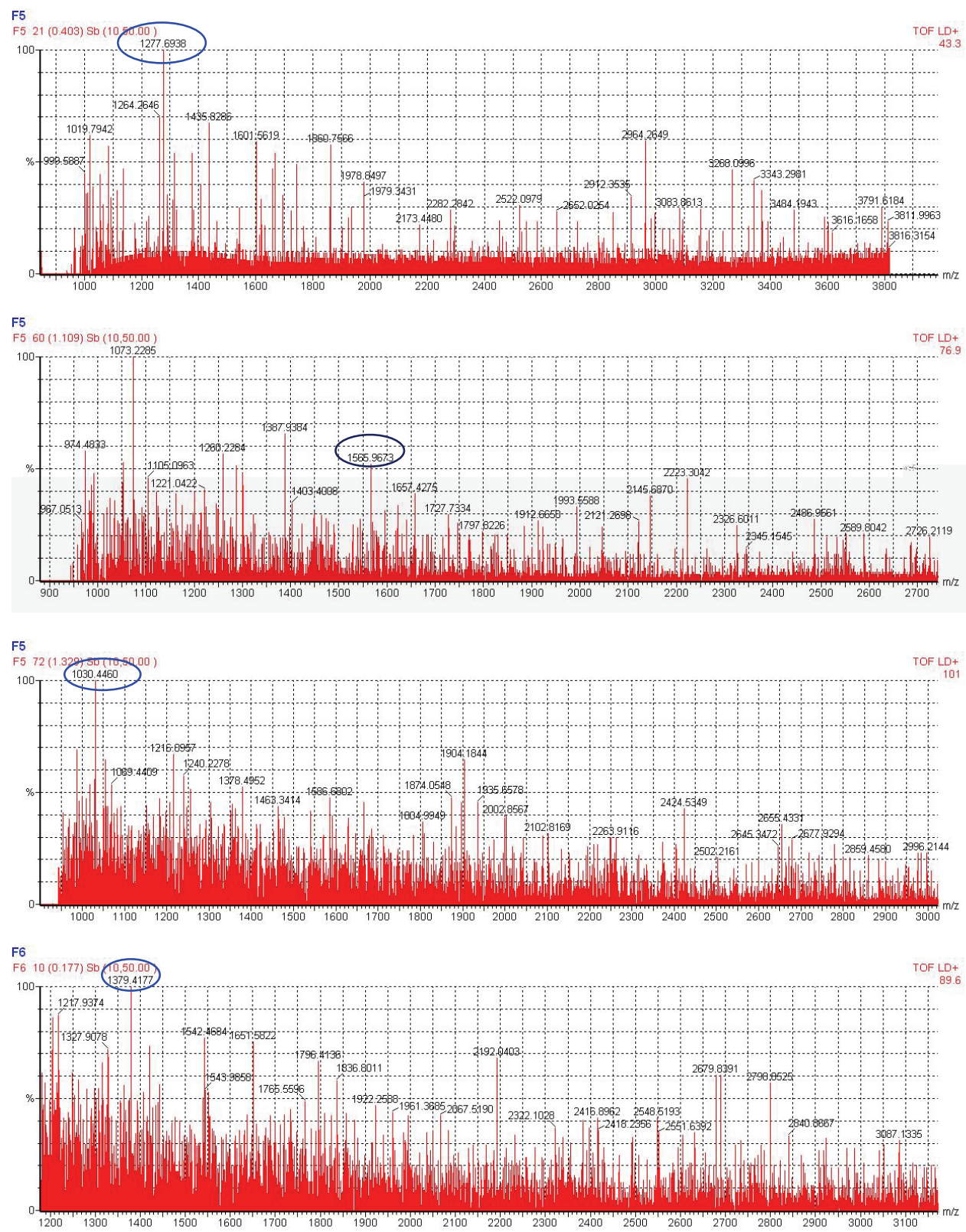

Figure 4: Peptides identified by trypsinization of CadC protein spot of MDN20 mutant strain Şekil 4: MDN20 mutantına ait CadC protein spotunda, tripsin kesimi sonucu tanımlanan peptitler

\section{Discussion}

$s t j$ fimbrial operon is one of the 13 putative fimbrial operons that is contained within the $S$. Typhimurium genome. Five genes of the $s t j$ fimbrial operon, $s t j A, s t j B$, $s t j C$, $s t j D$ and $s t j E$, were identified only by sequence analysis of $S$. Typhimurium genome (10). Until recently, there has been no information on the role of Stj fimbriae in virulence or persistence of $S$. Typhimurium in the host systems. Akkoc et al. (1) showed that $s t j$ fimbrial operon affected colonization and persistence of $S$. Typhimurium in mouse model systems. Protein sysnthesis patterns obtained from this study also confirmed that Stj fimbriae in $S$. Typhimurium was expressed in bacteria during infection in the host. Among 2500 serotypes, Stj fimbriae is present only in $S$. Typhimurium strain $(1,10)$. This indicates that determination of regulation characteristics in the $s t j$ operon in $S$. Typhimurium are also essential for the determination of the evolution of the serovars.

In our study, regulation of the stj fimbrial operon was determined by analyzing the DNA fragments amplified inverse PCR and by proteomic analyses. Our data indicate that $s t j$ fimbrial operon was regulated by CadC, a global transcriptional regulator in Salmonella. These findings are important for understanding Salmonella pathogenicity and evolution. During Salmonella infection in macrophages or in the stomach of the host; Salmonella is exposed to lethal acidic conditions (5). The survival of Salmonella under these acidic conditions depends on an acid tolerance response (ATR) (4). Perk et al. (14) demonstrated that the cadBA operon was involved in the ATR of $S$. Typhimurium. The cadBA operon encodes lysine decarboxlase (CadA) and 
lysine-cadaverine antiporter (CadB). The expression of the $\operatorname{cadBA}$ operon is dependent upon the transcriptional activator $\operatorname{CadC}(8,9,11,12,16,22)$. CadA has a $\mathrm{pH}$ optimum of 5.7 and converts lysine into cadaverine and $\mathrm{CO}_{2}$ (19). Although the structure of CadB has not been fully determined, it is well know that CadB is involved in the uptake or excretion of cadaverine (20). CadC is a 58 $\mathrm{kDa}$ protein that binds to a region of the genome that is located at -144 to -122 and -89 to -59 bp from the transcription start site of the promoter which activates the operon $(4,24)$. CadC has three domains: the N-terminal DNA-binding domain, the transmembrane domain, and the C-terminal periplasmic domain (9). S. Typhimurim cadC was shown to be induced in both the small intestines and spleens of $\mathrm{BALB} / \mathrm{c}$ mice during the infection (9). In vivo induction of CadC protein indicated that this protein also induced the virulence and persistence of $S$. Typhimurium in host systems (9). Our findings obtained from this study showed that CadC protein probably plays a role in the regulation of another gene, which has a function in the virulence of $S$. Typhimurium. Further investigations such as determination of binding efficiency of regulator protein to $s t j$ operon or structural changes in chromosomal site, where $s t j$ operon is located, are needed to characterize the function of this operon, which is critically important for Salmonella pathogenicity.

\section{References}

1. Akkoç N, Özden B, Tan BG, Akçelik M (2009): The role of stj fimbriyal operone in the intestinal persistence of Salmonella Typhimurium in mice. Biologia, 5, 859-863.

2. Bradford MM (1976): A rapid and sensitive method for quantitation of microgram quantities of protein utilizing the principle of protein-dye-binding. Anal Boichem, 72: 248-254.

3. Chessa D, Winter MG, Nuccio SP, Tükel Ç, Baumler AJ (2008): RossE repress std fimbrial expression in Salmonella enterica serotype Typhimurium. Mol Microbiol, 68, 573-587.

4. Foster JW (2000): Microbial responses to acid stres, In $G$. Storzand $R$. engge-Aronis (ed.), Bacterial stress responses. ASM Press, Washington, DC.

5. Foster JW, Spector M (1995): How Salmonella survives against the odds. Annu Rev Microbiol, 49, 145-174.

6. Garrels M (1979): Two-dimensional gel electrophoresis and computer analysis of proteins synthesized by clonal cell lines. J Biol Chem, 254, 7961-7977.

7. Jakomin M, Chessa D, Baumler AJ, Casadesus J (2008): Regulation of the Salmonella enterica std fimbrial operon by DNA Adenine Methylation, SeqA, and HdfR. J Bacteriol 190, 7406-7413.

8. Kuper C, Jung K (2005): CadC-mediated activation of the cadBA promoter in Escherichia coli. J Mol Microbiol Biotechnol, 10, 26-39.

9. Lee YH, Kim BH, Kim JH, Yoon WS, Bang SH, Park YK (2007): CadC Has a Global Translational Effect during Acid Adaptation in Salmonella enterica Serovar Typhimurium. J Bacteriol, 189, 2417-2425.
10. McClelland M, Sanderson KE, Spieth J, Clifton SW, Latreille P, Courtney L, Porwollik S, Ali J, Dante M, Du F, Hou S, Layman D, Leonard S, Nguyen C, Scott K, Holmes A, Grewal N, Mulvaney E, Ryan E, Sun H, Florea L, Miller W, Stoneking T, Nhan M, Waterston R, Wilson RK (2001): Complete genome sequence of Salmonella enterica serovar Typhimurium LT2. Nature, 413, 852-856.

11. Meng SY, Bennett GN (1992): Nucleotide sequence of the Escherichiacoli cad operon: a system for neutralization of low extracellular $\mathrm{pH}$. J Bacteriol, 174, 2659-2669.

12. Merrell DS, Camilli A (2000): Regulation of Vibrio cholerae genes required for acid tolerance by a member of the "ToxR-like" family of transcriptional regulators. J Bacteriol, 182, 5342-5350.

13. Miller JH (1972): Expriments in Molecular Genetics. Cold Laboratory Press, Cold Spring Harbor, New York, USA.

14. Park YK, Bearson B, Ban, SH, Bang IS, Foster JW (1996): Internal pH crisis, lysine decarboxylase and the acid tolerance response of Salmonella typhimurium. Mol Microbiol, 20, 605-611.

15. Rappleye CA, Roth JR (1997): A Tn10 derivate (T-POP) for isolation of insertions with conditional (tetracyclinedependent) phenotypes. J Bacteriol, 179, 5827-5834.

16. Rhee JE, Kim KS, Choi SH (2005): CadC activates $p H$ dependent expression of the Vibrio vulnificus cadBA operon at a distance through direct binding to an upstream region. J Bacteriol, 187, 7870-7875.

17. Schmieger h (1972): Phage p22 mutants with increased or decreased transduction activities. Mol Genet Genom, 119, $75-88$.

18. Shevchenko A, Tomas H, Havlis J, Olsen JV, Mann M (2007): In-gel digestion for mass spectrometric characterization of proteins and proteomes. Nature Protocoles, 1, 2856-2860.

19. Soksawatmaekhin W, Kuraishi A, Sakata K, Kashiwagi K, Igarashi K (2004): Excretion and uptake of cadaverine by CadB and its physiological functions in Escherichia coli. Mol Microbiol, 51, 1401-1412.

20. Soksawatmaekhin W, Uemura T, Fukiwake N, Kashiwagi K, Igarashi K (2006): Identification of the cadaverine recognition site on the cadaverine-lysine antiporter CadB. J Biol Chem, 281, 29213-29220.

21. Tükel Ç, Akçelik M, de Jong MF, Şimşek Ö, Tsolis RM, Baumler AJ (2007): MarT activates expression of the MisL autotransporter protein of Salmonella enterica Serotype Typhimurium. J Bacteriol, 189, 3922-3926.

22. Watson N, Dunyak DS, Rosey EL, Slonczewski JL, Olson ER (1992): Identification of elements involved in transcriptional regulation of the Escherichia coli cad operon by external $\mathrm{pH}$. J Bacteriol, 174, 530-540.

23. Weening EH, Barker JD, Laarakker MC, Humphries AD, Tsolis RM, Baumler AJ (2005): The Salmonella enterica serotype Typhimurium lpf, bcf, stb, stc, std, and sth fimbrial operons are required for intestinal persistence in mice. Infect Immun, 73, 3358-3366.

24. Zhao B, Houry WA (2010): Acid stress response in enteropathogenic gammaproteobacteria: an aptitude for survival. Biochem Cell Biol, 88, 301-314.

Geliş tarihi: 04.04.2011 / Kabul tarihi: 31.05.2011 